\title{
"Care and feeding": the Asian environmental tobacco smoke consultants programme
}

\author{
M Assunta, N Fields, J Knight, S Chapman
}

Tobacco Control 2004;13(Suppl II):ii4-ii12. doi: 10.1136/tc.2003.005199

\begin{abstract}
See end of article for authors' affiliations

Correspondence to: Mary Assunta, School of Public Health, Room 129A, Edward Ford Building (A27), University of Sydney, NSW 2006 Australia; marya@health. usyd.edu.au
\end{abstract}

\begin{abstract}
Study objective: To review the tobacco industry's Asian environmental tobacco smoke (ETS) consultants programme, focusing on three key nations: China, Hong Kong, and Malaysia.

Methods: Systematic keyword and opportunistic website searches of formerly private internal industry documents.

Main results: The release of the 1986 US Surgeon General's report on second hand smoke provoked tobacco companies to prepare for a major threat to their industry. Asian programme activities included conducting national/international symposiums, consultant "road shows" and extensive lobbying and media activities. The industry exploited confounding factors said to be unique to Asian societies such as diet, culture and urban pollution to downplay the health risks of ETS. The industry consultants were said to be "...prepared to do the kinds of things they were recruited to do".

Conclusions: The programme was successful in blurring the science on ETS and keeping the controversy alive both nationally and internationally. For the duration of the project, it also successfully dissuaded national policy makers from instituting comprehensive bans on smoking in public places.
\end{abstract}

$\mathrm{T}$ he 1986 US Surgeon General's report on environmental tobacco smoke $(\mathrm{ETS})^{1}$ provided tobacco control with unprecedented policy leverage. The mounting scientific evidence that ETS was a carcinogenic indoor air pollutant caused legislators, principally in developed nations, to commence implementing smoking restrictions.

These developments greatly concerned the tobacco industry because smoking restrictions both limited smoking opportunities and accelerated the social unacceptability of smoking, a combination which threatened to reduce sales significantly. In response, a number of strategies were introduced by the industry throughout the 1980s and early 1990s. These included the establishment of so called independent industry sponsored research organisations such as the Center for Indoor Air Research (CIAR) ${ }^{23}$ and the Association of Research on Indoor Air (ARIA) in 1988² the 1993 "sound science" programme"; and central to this article, the ETS consultants programme. ${ }^{56}$

The aims, objectives and activities of the ETS consultants programme were spelt out in three key documents. ${ }^{7-9}$ The programme's aim was to develop "an international network of independent scientists who can publicly and credibly address inaccurate claims on the health effects of ETS. ${ }^{\prime 7}$ The core objective was to "...to place ETS in perspective-to demonstrate that a host of serious public health problems needs to be tackled by governments in certain countries before they address either indoor air quality in general, or ETS specifically."' Within five years the industry established an interlinked programme that covered the USA (1987), Europe (1988), Asia (1989), and Latin America (1991). ${ }^{6}$

The issue of ETS in the Asian region was raised within Philip Morris (PM) as early as $1984,^{10}$ but rose to higher priority in late 1988 . Initially instigated by PM, the company moved quickly to include its major transnational competitors: Brown and Williamson (B\&W), RJ Reynolds (RJR), British American Tobacco (BAT), and Japan Tobacco International (JTI) ${ }^{8}$ This industry wide approach was to be a distinct feature of the Asian programme contrasting to other programmes such as those in Europe financed solely by
$\mathrm{PM}^{6}$ and the Latin programme funded by PM and BAT. ${ }^{11}$ Involving the major transnationals allowed cost sharing of the \$3.9 million spent between $1989-94^{12-15}$ with BAT admitting: "It would be impossible for us to carry out any individual part of the programme ourselves for such a small sum." 16

The Asian programme, like those in other regions, was managed by the Washington based law firm Covington and Burling (C\&B): "[C\&B] lawyers, and John Rupp in particular, are the most experienced and well-informed individuals outside the industry in the ETS area."16

While the Asian programme shared many features with those in other regions, the industry drew upon several distinctly Asian features in an enduring effort to promote the importance of confounding variables in indoor air epidemiology and thereby avoid any undue focus on ETS: Asia's climate of extreme heat and high humidity, its culture (incense smoke from tiny Buddhist shrines and the widespread keeping of caged birds), and lifestyle (highly spiced food often prepared on smoky coal burners) were all highlighted throughout the programme. Attributes such as these set the Asian programme apart from those in operation elsewhere.

This paper reviews the tobacco industry's Asian ETS consultants programme. It traces Asian consultant recruitment,

Abbreviations: $\mathrm{AAOH}$, Asian Association of Occupational Health; ARIA, Association for Research on Indoor Air; ARTIST, Asian Region Tobacco Industry Science Team; ATC, Asian Tobacco Council Ltd; BAT, British American Tobacco; B\&W, Brown and Williamson; C\&B, Covington and Burling; CIAR, Center for Indoor Air Research; CNTC, China National Tobacco Corporation; $\mathrm{COSH}$, Council for Smoking and Health; EPD, Environment Protection Department; ETS, environmental tobacco smoke; $\mathrm{HBI}$, Healthy Buildings International; HK, Hong Kong; $\mathrm{HKTI}$, Hong Kong Tobacco Institute; IAl, Indoor Air International; IAQ, indoor air quality; JTI, Japan Tobacco Inc; KL, Kuala Lumpur; NMA, National Manufacturers Association; PM, Philip Morris Inc; PMAI, Philip Morris Asia International; RJR, RJ Reynolds; SH\&B, Shook, Hardy and Bacon; TI, Tobacco Institute; USEPA, United States Environment Protection Agency 
their training and management by lawyers from C\&B and their various activities including media appearances, exposure and confounder studies, and direct lobbying of national policymakers. The programme was largely successful in blurring public and political perceptions of the science on ETS and "keep[ing] the controversy alive" ${ }^{17}$ For the duration of the project, it successfully dissuaded national legislators from tightening up legislation banning smoking in public places (table 1 ).

While the industry recruited consultants throughout Asia, this paper focuses on their activities in three key Asian nations: China, Hong Kong, and Malaysia. These three countries are significant for quite specific and differing reasons: China, not only for its enormous market potential, but the unparalleled impact ETS controls would have on sales; Hong Kong, because it was the industry's regional administrative base; and Malaysia, for its renowned business friendly environment and potential to establish a noninterventionist government model.

\section{METHODS}

This review is based on revelations from tobacco industry document searches conducted on the Master Settlement Agreement websites of PM, RJR, Lorillard, The Tobacco Institute, The Council for Tobacco Research, B\&W, and the American Tobacco Company. Additional searches were conducted on secondary document collection websites such as Tobacco Documents Online, Legacy Tobacco Documents Library, National Clearing House on Tobacco, and British Columbia's Tobacco Industry Documents site. Documents on these sites are indexed according to an agreed set of fields.

Initial searches focused on geographic terms representative of the Chinese, Malaysian, and Hong Kong regions. These included country names, cities, regions, and tobacco manufacturing sites truncated using the appropriate site syntax. Search words incorporated synonymous terms representative of the concept, acronyms, abbreviations, and variations of

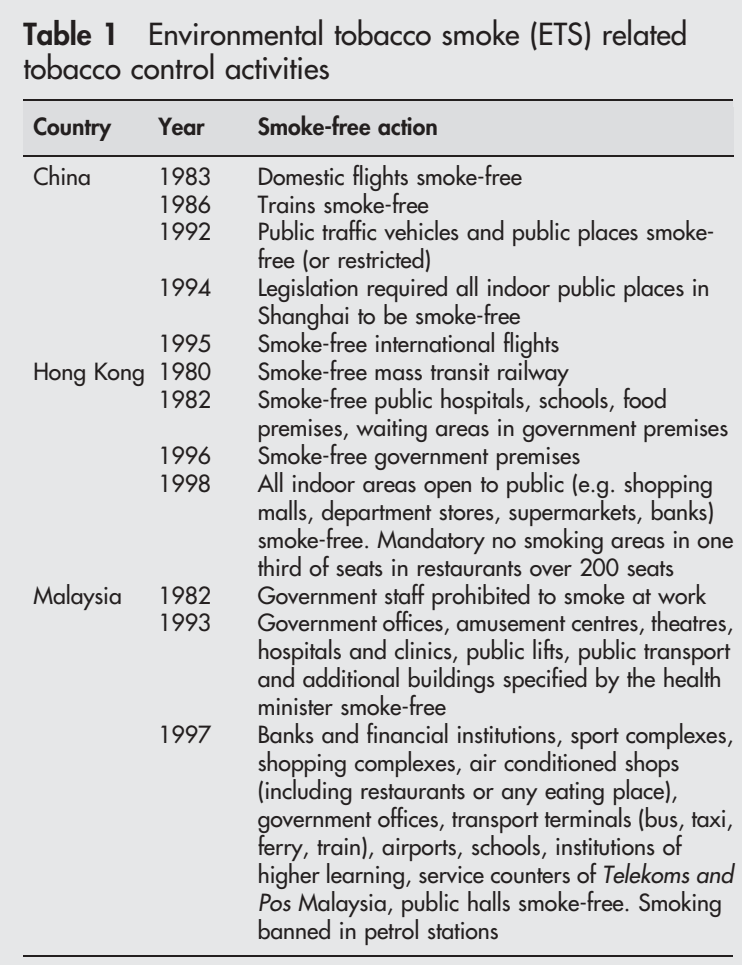

spelling. The results of these searches were then sorted by date and evaluated according to their degree of importance. During this process, the metadata for documents considered to be of high value were screened for clues to facilitate further searches (http://tobacco.health.usyd.edu.au/site/gateway/docs/ research.htm\#search).

\section{RESULTS}

The importance of utilising scientists from within the Asian region was emphasised: "It is essential to have scientists working in the region who are able to contribute in a balanced fashion to the debate. ... It is not acceptable to rely on scientists from other regions of the world."16 Local recruitment and training was based: "...on recognition of the fact that there were essentially no local scientists with a background in ETS issues and that experience elsewhere has shown that it is essential to have credible, local scientists prepared to speak out when ETS becomes an issue, which often occurs on short notice."18

The industry recognised that the unique conditions in Asia could be promoted as reasons for precluding the use of research to inform policy where this research had been conducted in more temperate and less vehicle polluted regions:

\section{"...the climate (both indoors and outdoors) in Far Eastern countries is very different from Western countries. ... [There are] serious outdoor air pollution problems that differ from those observed in the West. It is therefore not credible to rely on research in the USA and Europe to indicate levels of ETS present in typical indoor air environments... Such research needs to be carried out in the Far East and would enable us to put ETS into perspective in typical environments encountered in the region. ${ }^{\prime 16}$}

\section{Recruitment of consultants}

Rupp was responsible for every facet of the recruitment process in Asia. Following previous experience in Europe, Rupp hired the Washington DC consulting firm Washington Technical Information Group (Washtec) to identify and provide information on candidate consultants. ${ }^{19} 20$ The initial recruitment trips were undertaken by George Leslie, coordinator of the British based Association for Research on Indoor Air (ARIA) and David Billings from C\&B. Four initial target markets (HK, Philippines, Taiwan, and Korea) were selected and a recruitment goal of eight to 10 consulting scientists was set. ${ }^{18}$

Leslie and Billings undertook two recruitment trips in 1989. ${ }^{21}{ }^{22}$ There was a standard procedure for each meeting. ${ }^{17}$ The recruiters met with each potential consultant. If the scientists appeared interested in the broad concepts, details of the specific project (and its connections with the industry) were shared. A literature pack, containing relevant background material, was left with each interested scientist who was asked to study the material and report back. If the scientist did not appear interested the meeting was concluded, but always amicably.

The first recruitment trip covered Thailand, Philippines, Korea, and then HK where they met with Dr Alun McIntyre, Consultants in Environmental Sciences (Asia), Dr Sarah Liao, EHS Consultants Ltd, and Dr Linda Koo, Department of Community Medicine, University of Hong Kong. McIntyre, who headed up a consulting firm of environmental scientists and engineers, was considered useful in diminishing the importance of "ETS in the larger context of indoor air 


\begin{tabular}{|c|c|c|c|}
\hline Country & Name & Affiliation & Area of Expertise \\
\hline \multirow[t]{2}{*}{ China } & Dr Fengsheng $\mathrm{He}$ & $\begin{array}{l}\text { Director, Institute of Occupational Medicine Chinese } \\
\text { Academy of Preventative Medicine }\end{array}$ & Toxicology \\
\hline & Dr Guangguan Liu & $\begin{array}{l}\text { Chair, Department of Air Pollution Control, Institute of } \\
\text { Environmental Health \& Engineering }\end{array}$ & Outdoor pollution \\
\hline \multirow[t]{4}{*}{ Hong Kong } & $\begin{array}{l}\text { Dr John Bacon-Shone } \\
\text { Dr Linda Koo }\end{array}$ & $\begin{array}{l}\text { Department of Statistics, University of Hong Kong } \\
\text { Department of Community Medicine, University of } \\
\text { Hong Kong }\end{array}$ & $\begin{array}{l}\text { Biostatistics/environmental epidemiology } \\
\text { Scientist/ETS Epidemiology }\end{array}$ \\
\hline & Dr Sarah Liao & EHS Consultants Ltd & Occupational health \\
\hline & Dr Alun Mclntyret & Director, Consultants in Environmental Sciences (Asia) & Environmental science \\
\hline & Dr Clive Ogle & Department of Pharmacy, University of Hong Kong & Pharmacology \\
\hline \multirow[t]{2}{*}{ Malaysia } & Dr Krishna Rampal & $\begin{array}{l}\text { Department of Community Medicine, National University } \\
\text { of Malaysia }\end{array}$ & Occupational health \\
\hline & Dr Heng Huat Lim & $\begin{array}{l}\text { Mediviron Consultants Pty Ltd, Member, Malaysian } \\
\text { Institute of Engineers }\end{array}$ & Engineering \\
\hline Korea & Dr Yoon Shin Kim & $\begin{array}{l}\text { Associate Prof of Environmental Sciences, College of } \\
\text { Medicine, Hanyang University }\end{array}$ & Indoor air pollution \\
\hline \multirow[t]{4}{*}{ Philippines } & Dr Luis Ferrer & $\begin{array}{l}\text { Director, Health Infrastructure Services, Philippine } \\
\text { Ministry of Health }\end{array}$ & Architect \\
\hline & Dr Marilyn Go* & Manila (Affiliation unknown) & Paediatrics \\
\hline & Dr Benito Reverente & $\begin{array}{l}\text { WHO Occupational Health Panel, Ex-President, AAOH, } \\
\text { Lecturer, University of Philippines }\end{array}$ & Occupational health \\
\hline & $\begin{array}{l}\text { Dr Camilo Roa Jr } \\
\text { Dr Lina Somera }\end{array}$ & $\begin{array}{l}\text { Manila Medical Centre; Lung Centre of the Philippines } \\
\text { Head, Department of Public Health, University of the Philippines }\end{array}$ & $\begin{array}{l}\text { Chest physiology } \\
\text { Public health }\end{array}$ \\
\hline Singapore & Dr Choong Nam Ong & National University Hospital & Occupational health \\
\hline Thailand & $\begin{array}{l}\text { Professor Malinee } \\
\text { Wongphanich* }\end{array}$ & $\begin{array}{l}\text { Faculty of Public Health, Mahidol University, President } \\
\text { AAOH }\end{array}$ & Occupational health \\
\hline
\end{tabular}

pollution". ${ }^{21}$ Billings described the meeting with Sarah Liao as "extremely positive" ${ }^{21}$ however:

\section{"She has declined offers to consult on smoking and health... more for pragmatic than philosophical reasons. ...She appears to have great integrity and objectivity as a scientist and criticizes the health lobby for its inquisitorial tactics and scientific bias. ...Given her specialty and her practical aversion to tobacco-funded work, however, it is unlikely that she can act as a consultant. At the same time, I would not write her off completely. ${ }^{\prime 21}$}

When meeting with Koo, Leslie and Billings asked her if she would be willing to talk with their consultants on the epidemiology of ETS. They reported that she "indicated a willingness to help us in a private capacity". ${ }^{21}$

A second recruitment trip covered Korea and HK. While in HK, Leslie met Liao and Koo. At that time Liao, despite Billings' initial reservations, agreed to join the consulting group ${ }^{22}$ and proposed that she: “...act as an intermediary and buffer between Koo and our group. Koo would invoice Liao for any work she does on our behalf, and Liao would in turn be paid by us." ${ }^{22}$

Meetings were also held with Dr Clive Ogle and Dr John Bacon-Shone. Both agreed to attend a preliminary orientation session in Bangkok. Ogle had "some reservations about associating with us and questioned his contribution to the project". ${ }^{22}$ Billings concluded however that once "he [Ogle] begins to relax a little and sees the caliber of the scientists he will be associating with... Ogle can fulfill an important role as the only pharmacologist on our panel."22

At the conclusion of these two recruitment trips Rupp advised that 10 scientists had been identified, adding: "we have reestablished a productive ongoing working relationship with Dr. Linda Koo, who is the single most prominent ETS scientist in all of Asia. Although Dr. Koo...cannot afford formally to join our group, the ability we have developed to consult with her should pay substantial dividends."12
At the October 1989 meeting of participating company representatives, BAT requested, as a condition of their support, that consultants be "developed" in Malaysia and Singapore. ${ }^{16}{ }^{18}$ Additional consulting scientists were recruited from Malaysia (Krishna Rampal), China (Fengsheng He and Guangguan Liu), Singapore (Choong Nam Ong), and the Philippines (Luis Ferrer and Camilo Roa Jr). ${ }^{18}$ The Chinese recruit, He, was an active participant in the major occupational health organizations in Asia and was expected to succeed Malinee Wongphanich (the Thai consultant) as president of Asian Association of Occupational Health $(\mathrm{AAOH}) .^{18}$

Consultant recruitment was ongoing as some moved away from the region or proved to be unproductive or inappropriate. ${ }^{23}$ Additional consultants were later recruited such as Heng Huat Lim of Mediviron Consultants Pty Ltd and member of the Malaysian Institute of Engineers. Lim was described as being "extremely valuable to us on the ETS issue". ${ }^{24}$ A 1991 BAT internal memo noted the programme had 20 consultants in HK, Malaysia, China, Singapore, Indonesia, Japan, Korea, Taiwan, Philippines, and Thailand. ${ }^{9}$ Among the consultants were the past, present, and future presidents of the AAOH: "a very influential health organization in the region. These consultants have provided us with many opportunities to carry out seminars etc. under the auspices of the AAOH." ${ }^{\prime \prime}$ Having consultants affiliated with the AAOH further strengthened the credibility of industry's arguments. The industry used a similar strategy in the Latin programme. The outcomes of the early recruitment drives are summarised in table 2 .

\section{Coordination and training}

The first cohort of consultants attended a training workshop in Bangkok in June 1989. ${ }^{26}$ The focus was on developing "...a core group of scientists who are fully trained on the relevant issues and have developed sufficient enthusiasm to be prepared to make a real contribution-by way of writing articles, participating on our behalf at scientific 
meetings, joining industry people at briefings of government officials..."12

Consistent with the global consultants programme ${ }^{6}$ the industry enlisted at least four core experts who acted as resources for Asia. George Leslie of ARIA described himself as "an independent consultant in toxicology and risk assessment." His position on ETS mirrored the industry's:

"Environmental Tobacco Smoke (ETS) cannot be considered a serious health risk. In high concentrations it can be an irritant and it can be annoying. These effects can generally be resolved by adequate ventilation. ...the countries of Asia have far more serious and pressing problems of indoor air pollution than that presented by ETS. ${ }^{\prime 27}$

He was joined by Professor Roger Perry from Imperial College, London, Gray Robertson (HBI), and Joe Robertson (HBI Australia), ${ }^{28}$ long time consultants to the industry. ${ }^{29} 30$ The Asian consultants received industry approved literature on ETS from $C \& B^{31}$ who also promoted them as a group of "consultants in indoor air quality" by advertising their services in a brochure to solicit projects for them. ${ }^{32}$

In February 1990 Rupp reported to the companies that, since the October 1989 meeting, the orientation of their consulting scientists had "continued at a reasonably intensive level" and that the local national manufacturers association assisted in facilitating the local activities such as arranging meetings with government officials and preparation of articles for publication. ${ }^{18}$ With five companies now involved meetings were planned for every $2-3$ months in $\mathrm{HK}^{28}$

A subsequent training session (Manila 1990) was held for new consultants from Taiwan, Indonesia, Singapore, and Malaysia. ${ }^{13}$ Training of consultants continued locally when the core experts visited individual countries. Within each company, communication on the ETS issue was closely coordinated. In BAT, for example, Sharon Boyse managed communication flow among the subsidiaries:

"All queries and comments about the program should be fed back to me at Millbank to simplify communications with Covington \& Burling and other supporting companies. This includes any requests to make use of consultants etc. in a particular market. ${ }^{\prime 28}$

By 1990, Billings and Rupp sensed that, now in its second year, the nurturance of the group was about to reap dividends. Some consultants were judged as ready to advance arguments they had previously been "unwilling to make" thanks to "care and feeding" and "some practical training" provided by Perry and Leslie on "how to deal with government officials". ${ }^{33}$ The industry could now stay in the background with "clean hands." ${ }^{33}$ Rupp and Billings reported: “...we can provide a much higher level of public consultant activity than occurred last year. Having now achieved a reasonable command of the relevant literature, and with a substantial level of enthusiasm for the project, our consultants are prepared to do the kinds of things they were recruited to do..."18

\section{International conferences/symposia and national seminars}

Previous research has documented the industry funded international ETS symposium in McGill University, Montreal, ${ }^{11}$ but its significance for Asia was slightly different. It was a launching pad for a number of Asian consultants who presented papers later distributed to key people by Perry, who had many contacts in Asian government departments. ${ }^{28}$ As in the Latin Project ${ }^{11}$ the industry wanted to ensure that the "right people" were those "who have responsibility for or influence over public policy related to indoor air quality or ETS". ${ }^{34}$

By January 1990, translated papers from the McGill symposium were being distributed to key scientific and government personnel in HK, China, Korea, Japan, and Taiwan. ${ }^{35}$ These and other conference papers became important lobbying tools. ${ }^{34}{ }^{36-40}$ The 1990 industry sponsored Lisbon Indoor Air Quality Conference was another significant meeting for the Asian consultants because it aimed at: "...discussing indoor air quality issues in the context of warm climates." ${ }^{28}$ A number of Asian consultants attended the conference and presented papers.

The industry also produced national seminars to shape local debate on ETS and brought key government officials and third parties on board. ${ }^{23} \mathrm{C} \& \mathrm{~B}$ arranged for speakers to attend these conferences. ${ }^{41}$ In Malaysia the industry's main consultant, Lim, organised ETS related conferences in Kuala Lumpur (KL) ${ }^{42}{ }^{43}$ Rupp records the success of one of these:

"...our core presenters performed well. ...Mr. Leslie... noted...that the science of ETS has been manipulated by members of the worldwide antismoking community beyond any sensible recognition. He followed that observation with a plea that Malaysian policy makers not squander precious public health resources on ETS, which he characterized as a largely manufactured issue. ...Joe [Robertson] did an excellent job explaining the real causes of indoor air pollution in Kuala Lumpur." 44

Rupp advised the Confederation of Malaysian Tobacco Manufacturers on specific lobbying activities for follow up: "The government officials and reporters who attended one or more of the sessions should receive...the lion's share of our immediate attention. ...We recommend that efforts be made to identify potential allies in connection with smoking restriction proposals, particularly individual restaurants and restaurant groups, employer/employee groups..."44

The programme also sought the support of prestigious institutions to add credibility to its activities. In 1993 Perry approached an enthusiastic head of the British Council in HK and the HK British Trade Commissioner about funding ETS related seminars. ${ }^{45}$ British Council seminars and healthy building seminars subsequently took place in several Asian countries. ${ }^{46}$ Here PM saw the need to influence the debate: "There will be a large turnout and it seems to me that there will be key people there, many of whom will be saying just what we don't want them to say. For this reason we need a good presenter and a good advocate. ...If we don't, my guess is that the general consensus will be that buildings should play safe and ban smoking." ${ }^{47}$

Table 3 summarises the main activities in which the Asian consultants were engaged.

\section{Speaking tours to lobby legislators}

Speaking tours by the core experts enhanced local activities and were useful in lobbying national legislators. ${ }^{49}$ In HK, consultants' lobbying efforts succeeded in deterring legislators from banning smoking in restaurants. In 1989, Council for Smoking and Health (COSH) had submitted 24 recommendations to the Hong Kong Environment Protection Department (HK EPD) on tobacco control measures including a recommendation for non-smoking areas. To counter these recommendations Rupp and Leslie were invited by the Hong Kong Tobacco Institute (HKTI) to speak on ETS, arguing that HK's high pollution levels posed a greater risk to 
Table 3 Asian consultants' ETS activities

\begin{tabular}{|c|c|c|c|}
\hline Country & $I A Q$ survey & National/international conference & Materials distribution \\
\hline Hong Kong & 1990 & $\begin{array}{l}\text { National Tall Building Conference, } 1990 \\
\text { HKTE/ASHRAF/CIBSE Symposium, September } 1994 \\
\text { British Council Conference, October } 1994\end{array}$ & $\begin{array}{l}\text { McGill Symposium (translated papers) } \\
\text { Tokyo Monograph }\end{array}$ \\
\hline China & N/A & Symposium on IAQ, October 1994 (budget approved) & McGill Symposium (translated papers) \\
\hline South Korea & $\begin{array}{l}1993 \text { funded at Institute of } \\
\text { Environmental and Industrial } \\
\text { Medicine }\end{array}$ & Seminar, 1991 & McGill Symposium (translated papers) \\
\hline Philippines & 1990 EC funded & International Seminar on IAQ, 1990 & McGill Symposium \\
\hline Indonesia & $\begin{array}{l}1993 \text { funded at Institute of } \\
\text { Environmental and Industrial } \\
\text { Medicine }\end{array}$ & IAQ Symposium 1991 & $\begin{array}{l}\text { Publish IAQ symposium under University of } \\
\text { Jakarta; distribute to government departments } \\
\text { and selected media (recommended action) }\end{array}$ \\
\hline Singapore & Proposed for 1992 & Seminar-publicise data from Dr Lee's studies, 1994 & $\begin{array}{l}\text { Tokyo Monograph-1993 } \\
\text { ETS info to govt. dept. }\end{array}$ \\
\hline \multirow[t]{2}{*}{ Malaysia } & $1992 \mathrm{HBI}$ study & $\begin{array}{l}\text { IAQ Symposium in Asia, September } 1991 \text { and } \\
\text { September } 1992\end{array}$ & Other People's Tobacco Smoke-1993 \\
\hline & & $\begin{array}{l}\text { EnvironPro } 92 \text { Conference, October 1992; } \\
\text { International Scientific Conference, } 1993\end{array}$ & Tokyo Monograph-1993 \\
\hline Thailand & 1993 & International conference on IAQ in Asia, Nov 1991 & $\begin{array}{l}\text { Bangkok Monograph Indoor Air Symposium } \\
\text { (1993) }\end{array}$ \\
\hline Japan & 1993 & International Symposium on ETS, 1993 & McGill Symposium (translated papers) \\
\hline Taiwan & 1993 & Indoor air seminar (recommended action) & $\begin{array}{l}\text { McGill Symposium (translated papers) } \\
\text { Tokyo Monograph - } 1993\end{array}$ \\
\hline
\end{tabular}

health than ETS. ${ }^{50}{ }^{51}$ A February 1990 memo summarised the industry's successes in forestalling the 24 recommendations: “...Brenda [Chow] painstakingly steered the industry through an extremely tough year with intensive lobbying on all levels. Under her leadership, the HKTI accomplished ... The creation of an effective restaurant coalition to thwart COSH's recommendation to impose a $50 \%$ smoking ban in restaurants. ...As a result of the coalition's successful lobbying activities, COSH's recommendation was watered down by the government." ${ }^{152}$ Lobbying HK government officials continued into 1993. Liao organised meetings between PM consultants, the HK EPD, and legislators ${ }^{53}$ which revealed "the EPD does not currently plan to impose further smoking restrictions before 1997". ${ }^{45}$

In August 1993 Perry and Leslie, at a cost of \$54 000, (covering travel and expenses) ${ }^{53}$ went on an ETS road show to nine Asian cities, including $\mathrm{HK}$ and $\mathrm{KL}$, with a view to "improve our situation over the moderate to longer term". ${ }^{53}$ Frequent visits by the core experts saw the dissemination of a consistent pro-industry message. Following the August visit by Leslie and Perry, in November, Joe Robertson met with Malaysian government officials, arranged by the industry's local consultant. He conveyed that:

"... ETS is not a major source of indoor air quality problems in Malaysia, and that the Australian experience shows that the problems indoor smoking restrictions cause, especially for the hotel and restaurant industries, are disproportionate to the limited air quality improvements they may bring. ${ }^{\prime 54}$

\section{Utilising media}

Within the global programme a range of media strategies were developed:

"Get scientists who are against us on the primary issue [i.e., active smoking] to speak up in our favor on the ETS issue. ...We should attempt to arrange debates between these scientists and the more rabid or silly antis... We should identify celebrities or well-known spokespersons, who are not scientists, who will appear on television, to give media interviews, etc. and explain the other side of the story on ETS. ... we should push the notion that these people are of such stature that they cannot be corrupted by receiving a few thousand dollars from the tobacco industry..."

In the Asian context, the news media were vital, with the core experts achieving substantial publicity through media tours, and local consultants writing regular columns in newspapers and countering negative press on ETS. In 1989 consultant tours in Asia resulted in approximately 100 media reports, including "favorable TV and radio interviews". ${ }^{56}$

In Malaysia, Rupp liaised with the local consultant Lim, to write a series of articles at a cost of $\$ 20000^{48}$ for a leading KL newspaper ${ }^{39}$ on occupational health issues. Local subsidiaries were also provided with model answers for frequently asked questions when dealing with the press. For example:

\section{"It's interesting, isn't it, how fashions change? What you refer to now as a 'stink' was at one time seen to be rather pleasant. Don't you think it would be wrong to ban things because they become less 'fashionable'... Some people find perfume annoying. That's no reason to ban perfumes, is it? ? $^{\prime \prime}$}

With the January 1993 release of the United States Environment Protection Agency (USEPA) report on ETS ${ }^{58}$ the global industry "... hit back hard, accusing the EPA of putting its own spin on statistics to justify a political vendetta against tobacco" ${ }^{\prime 59}$ Despite industry efforts, numerous articles about the report, negative to the industry, appeared in the Asian press. ${ }^{580-64}$ An internal PM memo noted the exposure to be "fairly extensive". However, news coverage of the USEPA report in the English press was minimal. ${ }^{65}$

\section{The science}

As discussed, the industry was intent on capitalising on notions that Asian circumstances were different to those in the West where restrictive smoking policies were proliferating: "The question for the future is the extent to which countries in Asia will be prevailed upon to adopt Westernstyle smoking restrictions-or whether, alternatively, Asian nations will choose to chart an independent course, one that takes into account their own special circumstances and cultural imperatives." ${ }^{\prime 66}$ IAQ in the West was said to be "often radically different qualitatively and quantitatively from those 
of Asia. ...Asian nations need to identify and prioritise concerning their own problems and their own methods of improvement and treatment of the indoor air quality."

As a result "[Studies were commissioned] In an attempt to base Asian debate on ETS on a sound scientific basis and to communicate the relative contribution of ETS to the indoor and outdoor environment to the public and regulators in the climatically, culturally and economically heterogeneous Asian/Pacific regions..." ${ }^{\prime 68}$

Monitoring protocols for these studies designed to divert attention from risks posed by ETS by focusing on outdoor air pollution were developed by industry appointed representatives and approved by industry scientists. ${ }^{31} \mathrm{HK}$ was one of the major industry target cities as a result of $\mathrm{COSH}^{\prime}$ s strong antitobacco recommendations. In the late 1980s, gathering evidence via air quality studies in HK restaurants was a major industry task. ${ }^{69}$ At a cost of approximately \$250 000 each, a series of ETS exposure studies were planned and funded by PM, BAT, and JTI: "The funds would be provided to CIAR, the organization responsible for the independent scientific quality of the studies and the monitoring of the project." 68

In confidential 1995 correspondence, Rupp advised colleagues that Sarah Liao's firm EHS Consultants had been selected as finalists in the bidding for the HK government air quality study: “a very substantial achievement ... precisely the sort of result the ETS Consultants Program is designed to achieve." ${ }^{\prime 70}$ Liao's firm was awarded the $\$ 1$ million contract, causing a CIAR official to congratulate itself on previous support to ETS science in Asia:

"The contract was awarded to EHS after a tough competitive bidding process. I am convinced, in part because officials of the Environmental Protection Department in Hong Kong have said so, that EHS was awarded the contract in part because of indoor air quality monitoring work that they had completed previously for CIAR. That previous work showed, incidentally, that smoking does not contribute significantly to indoor air problems here. ${ }^{\prime \prime 7}$

ETS science was still on industry agendas in the late 1990s with both PM and RJR involved in funding research. However, as part of the Master Settlement Agreement, the CIAR was disbanded in $1999 .{ }^{72}$

The industry also invested in promoting the role of possible factors such as diet, coal burning, vitamin C, beta-carotene, Fusarin C, bacteria/fungi, and nitrosamines in confounding the purported relationship between ETS and disease. Koo's research in confounders was extensive $e^{73-75}$ and industry exploited her expertise:

\footnotetext{
"In a series of scientific articles, Dr. Koo has reported that diet, independent of exposure to ETS, appears to be associated with the relatively high incidence of lung cancer among non-smoking Chinese women in Hong Kong. In particular, Dr. Koo reported that vegetables, meats and fish that are smoked, salted, cured or pickled are associated with an increased lung cancer risk while fresh versions of those foods are not. ${ }^{\prime \prime 36}$
}

A statement released by George Leslie extolled Koo's work concluding:

"...the countries of Asia have far more serious and
pressing problems of indoor air pollution than that
presented by ETS. Warm, humid climates are conducive to serious problems from bacteria and fungi. Not the least of your problems here in Hong Kong is the level of external air pollution generated by road traffic and industry. ... It is my view that Hong Kong has more important tasks to undertake than following Western fads and fancies. ${ }^{\prime 27}$

In 1992 PM released a pamphlet, "Environmental tobacco smoke: a perspective based upon the science", ${ }^{36}$ which emphasised confounders: "A major cause [of sick building syndrome] appears to be poor quality outside air, which too often is not filtered properly before being brought indoors. Another major problem, documented repeatedly, is presence of bacteria, fungi and dust within building ventilation systems... A third problem category, which is more common to Asia, involves indoor cooking and heating methods-often occurring without venting to the outside the substantial quantities of smoke and chemical pollutants." ${ }^{\prime 36}$

In a November 1992 memo, consultant Ragnar Rylander reported on a meeting with Koo "to review ongoing research projects with particular reference to ETS and to explore possible joint projects for the future" such as the diets of nonsmokers married to smokers and bird keeping as risk factors for lung cancer. ${ }^{76}$ The industry's reading of the science from China also highlighted confounder arguments:

\section{"Overall it looks as if for China genetic parameters (high proportion of fast acetylators, family history of diseases), modulating factors (e.g. diet) and other exposures (e.g. from smoky coal) play an important role as parameters possibly associated with lung cancer. Compared to these, ETS appears to have no or minor contribution to claimed associations. ${ }^{177}$ (Emphasis in original).}

Roger Walk of PM Europe recommended: “[Koo's] work should be supported especially with regard to the possibility of integrating aspects such as improved biomonitoring and molecular epidemiology into her work. I would also recommend supporting her collaboration with researchers in other parts of China to help them share her thorough understanding of these critical factors and to prevent false interpretations by less experienced epidemiologists." ${ }^{177} \mathrm{Koo}^{\prime} \mathrm{s}$ research received wide publicity, advanced by the industry. A press release from RJR and carried in the South China Morning Post commenced: "Hong Kong researchers [Linda Koo and John Ho] say the food Chinese people eat, rather than the cigarette smoke they inhale, is the main cause of lung cancer. ...The researchers said the Chinese preference for preservatives, fatty meats and pickles, which are heavy in N-nitroso, is the main cause of lung cancer." ${ }^{178}$

However, cracks in the programme began appearing during the mid $1990 \mathrm{~s}^{79}$ with it being described as "in a state of significant transition-and, quite possibly, reeling toward an inelegant collapse. Some effort has gone into fixing both the problems and the program, but at this point, it is more damage control than anything substantive. Notwithstanding the industry's problems, ETS is a growing and important issue in Asia-even though with the exception of a few markets, it is not yet a lost battle. There is some time, but not much." 79

While the ETS programme may have been falling into disarray, efforts continue to develop a coherent regional group with the formation of Asian Region Tobacco Industry Science Team (ARTIST), "established to exchange relevant scientific information and to coordinate programs in the region". ${ }^{80} 81$ A 1996 document on PM Asia Scientific Affairs plan described one of its core goals: "ETS as an issue has not yet been 'fully developed' in the region in the minds of policy makers, and the Region's Corporate Affairs management has 
initiated programs to: (1) maintain or improve the social acceptability of smoking in Asia..., ${ }^{\prime 80}$ a goal the industry continues to strive for today.

\section{DISCUSSION}

ETS was seen as the "single most important challenge" ${ }^{82}$ to the industry and posed a major threat to its business. As Rupp succinctly stated when describing the industry's current position on ETS in 1987: "Where we are-In deep shit" ${ }^{\prime 83}$ because the "... scientific battle was lost with [the] SG's '86 report." ${ }^{\prime 3}$ The internal documents show the issue brought the intensely competitive companies together to confront the mutually damaging ETS issue collectively and pour "millions" ${ }^{84}$ into devising counter measures and activities that were rigorously executed by C\&B.

While globally the industry's ETS consultants programme was to pre-empt smoke-free legislation, regionally the programme addressed specific issues. The Asian programme and its Latin counterpart ${ }^{11}$ differed significantly in their focus: the Asian programme was broadly charged with preempting comprehensive, national smoke-free legislation; the instigation of the Latin programme was more focused to address the impact of the USEPA report in that region, a report that had minimal impact in Asia. The financial basis of the two programmes also differed: the Asian programme was funded by PM, BAT, RJR, Rothmans, and JTI while the Latin program's funding was limited to PM and BAT only. Unlike the programme in the USA, both the Asian and Latin programmes were successful in co-opting well placed scientists.

The ETS programme was successful in delaying and diluting smoke-free legislation in Asia because Asia presented certain exploitable characteristics. Approaching the issue regionally and industry-wide put the industry in a strong position to shape the debate to suit the Asian context, engineer the research accordingly, and frame the issue appropriately for policymakers. Asian governments hold local academics and researchers in particularly high regard. The industry carefully hand picked and recruited malleable academics and researchers in medicine, public health and environmental institutes to give a high level of credibility to the industry's activities and proposals. Asian cities also presented a huge, insurmountable outdoor air pollution problem that provided a convenient diversion to convince policymakers that ETS risks were trivial. The industry framed the debate around how outdoor pollution directly affected indoor air quality, making it "far more serious and pressing $^{\prime 27}$ than problems presented by secondhand smoke. Any solutions to indoor air therefore should address the seemingly insurmountable problem of outdoor air pollution as the principal source of indoor air pollution. Studies and surveys focused on substantiating this preordained conclusion. The seminars provided a platform to present and publicise the conclusions that were further reinforced by publications pushing a pro-industry position. ETS was trivialised as a Western "fad and fancy". ${ }^{27}$

Lack of finance for public health made both governments and academic institutions alike welcome industry funding. Through the ETS programme, the industry was on hand to finance research to address two important issues-environment and health. The plea made by the foreign experts not to "squander precious public health resources on ETS" ${ }^{44}$ likely struck a chord with cash strapped policymakers.

Though the documents record the successes achieved through the Asian programme, the industry itself had to contend with local initiatives proposed by those active in the tobacco control movement. The timing of the Asian ETS programme was significant in Asia as in 1989 Hong Kong presented an immediate challenge for the industry to

\section{What this paper adds}

The tobacco industry's efforts to create and sustain controversy and influence public policy on the secondhand smoke issue are well documented. This is the first paper based on a comprehensive industry document search to review the Asian ETS programme.

address. COSH was actively lobbying for smoke-free public places and the industry recorded how many of COSH's 24 recommendations were eventually "watered down by the government" through its recruits' efforts. In Malaysia several public places had already been declared smoke-free before the consultants programme was introduced, and the industry was fighting the government's initiative in 1992 to introduce broader tobacco regulations including bans on indirect advertisements, sponsorships and more smoke-free public places. China had already banned smoking in buses, allocated smoke-free carriages in trains, and all its domestic flights were smoke-free. In the early 1990s it was seeking to extend its smoke-free places. The industry's task was to preempt further regulations. While they often failed to pre-empt legislation altogether, in many cases they succeeded in watering them down.

Asia provided a conducive environment to engineer scientific research, explore possible confounding factors such as diet, coal burning, fungi and bacteria to produce "dramatic proof of our own", ${ }^{83}$ and redeem the "scientific battle" ${ }^{\prime 83}$ felt to have been lost with the 1986 US Surgeon General's report. ${ }^{1}$ As the Asian governments moved to increase smoke-free public places, creating doubt on the science was sufficient to buy some time.

\section{Conclusion}

Under its initial guise, the Asian ETS consultants programme was successful in blurring the science on secondhand smoke and keeping the controversy alive at both national and regional levels. According to industry financed scientists, everything but cigarette smoke was responsible for lung cancer in Asia. For the duration of the project, it also successfully dissuaded national policymakers from instituting comprehensive bans on smoking in public places. As evidenced in the documents, companies such as PM certainly continued to pay handsomely for the privilege of an Asian consultancy. The opening statement from their 1987 Operation Down Under meeting is salient: "We are here to do something radical. To look at a problem. To achieve a solution." ${ }^{83}$ The solution included subverting science on secondhand smoke for Asia and convincing regulators to accept industry's solutions.

\section{ACKNOWLEDGEMENTS}

The research reported in this paper was supported by grants from the National Health and Medical Research Council (2001-2003 \#153857) and the US National Institutes of Health (2001-2005 \#R01 CA87110-01Al).

\section{Authors' affiliations}

M Assunta, N Fields, J Knight, S Chapman, School of Public Health, University of Sydney, Sydney, NSW, Australia

\section{REFERENCES}

1 US Department of Health and Human Services. The health consequences of involuntary smoking. A report of the Surgeon General, 1986. Rockville, Maryland: Public Health Service, Centers for Disease Control, 1986. (DHHS Publication No (CDC) 87-8398). 
2 Drope J, Chapman S. Tobacco industry efforts at discrediting scientific knowledge of environmental tobacco smoke: a review of internal industry documents. J Epidemiol Community Health 2001;55:588-94.

3 Barnes DE, Bero LA. Industry-funded research and conflict of interest: an analysis of research sponsored by the tobacco industry through the Center for Indoor Air Research. Journal of Health Politics 1996;21:515.

4 Ong EK, Glantz SA. Constructing "sound science" and "good epidemiology": tobacco, lawyers, and "public relations firms". Am J Public Health 2001;91:1749-57.

5 Muggli ME, Forster JL, Hurt RD, et al. The smoke you don't see: uncovering obacco industry scientific strategies aimed against environmental tobacco smoke policies. Am J Public Health 2001;91:1419-23.

6 Muggli ME, Hurt RD, Blanke DD. Science for hire: a tobacco industry strategy to influence public opinion on secondhand smoke. Nicotine Tob Res 2003;5:303-14.

7 Whist A. Update-ETS Consultant Project. 18 May 1988. Philip Morris. Bates No. 2021546791/6792. http://legacy.library.ucsf.edu/tid/ykg44e00.

8 Philip Morris. Preliminary 1994 Consultants Program Proposal. 1994. Philip Morris. Bates No. 2023590685/0687. http://legacy.library.ucsf.edu/tid/ gwo $24 \mathrm{e} 00$.

9 Boyse S. Industry ETS Consultancy Programmes. 1991. British American Tobacco. Bates No. 300515335/5338. http://tobaccodocuments.org/ guildford_misc/300515335-5338.pdf [Accessed 6 Feb 2003].

10 Hoel DK. [Letter from Donald Hoel to Andrew Whist]. 27 Nov 1984. Philip Morris. Bates No. 2015029644/9646. http://legacy.library.ucsf.edu/tid/ bdq87e00

11 Barnoya J, Glantz S. Tobacco industry success in preventing regulation of secondhand smoke in Latin America: the "Latin Project". Tobacco Control 2002; 11:305-14.

12 Rupp JP. [Letter from John Rupp to John Dollisson]. 25 May 1989. Philip Morris. Bates No. 2500048635/8640. http://legacy.library.ucsf.edu/tid/ szf87e00.

13 Boyse S. Asia ETS programme. 18 Sep 1990. British American Tobacco. Bates No. 304002650/2654. http://tobacco.health.usyd.edu.au/tds/ BAT304002650_2654 [Accessed 12 Oct 2002]

14 Covington and Burling. Asia ETS Consultants Program Budget at June 14 , 1993. 14 Jun 1993. British American Tobacco. Bates No. 300536844 http://tobacco.health.usyd.edu.au/tds/BAT300536844 [Accessed 14 Feb 2003]

15 Rupp JP. [Facsimile from John Rupp to Program Colleagues]. 4 Nov 1993. Philip Morris. Bates No. 2063834924/4926. http://legacy.library.ucsf.edu/ $\mathrm{tid} / \mathrm{muj} 32 \mathrm{~d} 00$.

16 Boyse S. Far East ETS Project. 5 Jan 1990. British American Tobacco. Bates No. 304028746/8748. http://tobaccodocuments.org/guildford misc/ 304028746-8748.html [Accessed 6 Dec 2002].

17 Boyse S. British American Tobacco. Note on a Special Meeting of the UK Industry on Environmental Tobacco Smoke, London, February 17th, 1988. 17 Feb 1988. Philip Morris. Bates No. 2063791182/1187. http:// legacy.library.ucsf.edu/tid/kur45d00.

18 Rupp JP, Billings DM. Asia ETS Consultant Status Report. 14 Feb 1990. Philip Morris. Bates No. 2500048976/8998. http://legacy.library.ucsf.edu/tid/ zzd58d00.

19 Weinberg MS. [Letter from Washtech to John Rupp]. 10 Mar 1989. Brown \& Williamson. Bates No. 680709435. http://legacy.library.ucsf.edu/tid/ wip43f00.

20 Remes D. The PM EEC/EEMA ETS project:draft. 20 Feb 1988. Philip Morris Bates No. 2501474253/4259. http://legacy.library.ucsf.edu/tid/itg45d00

21 Billings DM. Asia ETS Consultants Project. 25 Feb 1989. Philip Morris. Bates No. 2500048655/8662. http://legacy.library.ucsf.edu/tid/vzf87e00.

22 Billings DM. Memorandum to Mr Rupp Re: ETS Project Update. 10 Apr 1989 Philip Morris. Bates No. 2500048643/8654. http://legacy.library.ucsf.edu/ tid/uzf87e00.

23 Boyse S. Far East ETS Programme. 26 Jul 1991. British American Tobacco. Bates No. 300541785/1789. http://tobaccodocuments.org/ guildford_misc/300541785-1789.html [Accessed 12 Oct 2002].

24 Rupp JP. [Letter from John Rupp to Clare Purcell]. 17 Jun 1993. Philip Morris. Bates No. 2023591046. http://legacy.library.ucsf.edu/tid/ kxf46e00.

25 Rupp JP, Billings DM. Asia ETS Project-Status Report. 27 Sep 1989. Philip Morris. Bates No. 2500048508/8515. http://legacy.library.ucsf.edu/tid/ kzf87e00.

26 Covington and Burling. Preliminary Programme-Bangkok Meeting. 22 Jun 1989. Philip Morris. Bates No. 2500048641/8642. http:// legacy.library.ucsf.edu/tid/tzf87e00.

27 Leslie G. Statement by George Leslie: Environmental Tobacco Smoke A Review of the Literature. 27 Jun 1989. Philip Morris. Bates No. 2500048789/ 8790. http://legacy.library.ucsf.edu/tid/iii19e00.

28 Boyse S. Far East ETS Project: Update. 14 Mar 1990. British American Tobacco. Bates No. 304028817/8819. http://tobacco.health.usyd.edu.au/ tds/BAT304028817_8819 [Accessed 14 Feb 2003].

29 Adams WA, Stuntz SM. 1993 Budget. 18 Sep 1992. Lorillard. Bates No. 92758651/8658. http://legacy.library.ucsf.edu/tid/bth70e00 [Accessed 11 Nov 2003].

30 Robertson G. Australia. 11 Sep 1991. Philip Morris. Bates No. 2024526046. http://legacy.library.ucsf.edu/tid/gta09e00 [Accessed 11 Nov 2003]

31 Rupp JP. [Letter from John Rupp to George Leslie]. 5 Jul 1989. Philip Morris Bates No. 2500048598/8600. http://legacy.library.ucsf.edu/tid/ $\mathrm{mzf} 8 \mathrm{7e} 00$.
32 Consultants in Indoor Air Quality Asia. Consultants in Indoor Air Quality (Asia) Ltd. Sep 1989. Philip Morris. Bates No. 2500048523/8524. http:// legacy.library.ucsf.edu/tid/oyh19e00.

33 Harris D. [Telex from Don Harris to Clare Purcell]. 28 Jun 1993. Philip Morris. Bates No. 2023591073/1074. http://legacy.library.ucsf.edu/tid/ Iwo $24 \mathrm{e} 00$

34 Harris D. McGill University ETS Symposium. 24 Jan 1990. Philip Morris. Bates No. 2504042040/2042. http://legacy.library.ucsf.edu/tid/ vnw19e00.

35 Donner RK. Asia ETS Project. 31 Oct 1990. R.J. Reynolds. Bates No 507657287/7288. http://legacy.library.ucsf.edu/tid/oub24d00.

36 Philip Morris Asia Inc. Environmental Tobacco Smoke: A Perspective Based Upon The Science. May 1992. Philip Morris. Bates No. 2504014425/4442. http://legacy.library.ucsf.edu/tid/qaul9e00.

37 Boyse S. Indoor Air Quality in Asia-Proceedings of the Conference Held in Bangkok 28-29 November 1991. 10 May 1993. British American Tobacco. Bates No. 300537072. http://tobacco.health.usyd.edu.au/tds/ BAT300537072 [Accessed 12 Oct 2002].

38 Boyse S. Asian ETS Consultancy Programme. 26 May 1993. British American Tobacco. Bates No. 300536953. http://tobacco.health.usyd.edu.au/tds/ BAT300536953 [Accessed 12 Oct 2002].

39 Rupp JP. [Letter from John Rupp to Haji Mohd. Arif Bador]. 15 Jun 1993 Philip Morris. Bates No. 2025841430/1432. http://legacy.library.ucsf.edu/ $\mathrm{tid} / \mathrm{xhw} 42 \mathrm{~d} 00$.

40 Boyse S. Japanese ETS Symposium Proceedings. Sep 1993. Philip Morris. Bates No. 2501247865. http://legacy.library.ucsf.edu/tid/cub29e00.

41 Rupp JP. [Letter from John Rupp to J.P. Lee]. 12 Feb 1990. Philip Morris. Bates No. 2504002792. http://legacy.library.ucsf.edu/tid/igw19e00.

42 Anon. [September Conference Listing]. Aug 1991. Philip Morris. Bates No. 2025810847/0853. http://legacy.library.ucsf.edu/tid/qtn 14e00.

43 Anon. [August Conference Listing]. 3 Aug 1992. Philip Morris. Bates No. 2025810327/0329. http://legacy.library.ucsf.edu/tid/gio85e00.

44 Rupp JP. [Letter from John Rupp to Haji Mohd. Arif Bador]. 16 Sep 1992. Philip Morris. Bates No. 2025841 187/1 191. http://legacy.library.ucsf.edu/ $\mathrm{tid} / \mathrm{ntr} 95 \mathrm{e} 00$.

45 Anon. Memorandum to the Hong Kong file Re: Perry Visit Summary (July 2628). Oct 1993. Philip Morris. Bates No. 2048771025. http:// legacy.library.ucsf.edu/tid/bnn32d00.

46 Tamussino P. ETS Consultants Program Malaysia Priorities 1994. 17 Nov 1993. Philip Morris. Bates No. 2048771015/1016. http:// legacy.library.ucsf.edu/tid/zmn32d00.

47 Goodheart J. Healthy Building Seminar. 20 Jun 1994. Philip Morris. Bates No. 2025837984A/7985. http://legacy.library.ucsf.edu/tid/ joy $83 \mathrm{e} 00$.

48 Covington and Burling. [Regional Recommendations and Funding Requirements for the Asian ETS Consultancy Programme]. 23 Mar 1993. British American Tobacco. Bates No. 300537135/7164. http:// tobacco.health.usyd.edu.au/tds/BAT300537135_7164 [Accessed 12 Oct 2002].

49 British American Tobacco. Asia-Pacific Plan: Bringing ETS to the Market. Undated. Brown \& Williamson. Bates No. 536486519/6527. http:// legacy.library.ucsf.edu/tid/iuo31fo0.

50 Oriental Daily News. Hazards of "Passive Smoking"? 28 Jun 1989. Philip Morris. Bates No. 2500048784. http://legacy.library.ucsf.edu/tid/ kji 19 e00

51 Dollisson J. 1989 2nd Revised Forecast Presentation-Corporate Affairs. 15 Jun 1989. Philip Morris. Bates No. 2500101311/1323. http:// legacy.library.ucsf.edu/tid/fml19e00

52 Fung J. HKTI AGM, February 16, 1989. 14 Feb 1990. Philip Morris. Bates No. 2504002913/2914. http://legacy.library.ucsf.edu/tid/qfw19e00.

53 Rupp JP. [Letter from John Rupp to George Leslie and Roger Perry]. 1 Jun 1993. Philip Morris. Bates No. 2025841423/1426. http:// legacy.library.ucsf.edu/tid/vhw42d00.

54 Tamussino P. Memorandum to the Malaysian File re: Joe Robertson Visit. 17 Nov 1993. Philip Morris. Bates No. 2048771019/1022. http:// legacy.library.ucsf.edu/tid/yac55d00.

55 Philip Morris. Environmental Tobacco Smoke. 1990. Philip Morris. Bates No. 2021 183691/3692. http://legacy.library.ucsf.edu/tid/ukp87e00.

56 Whist A. ETS. 11 Jul 1989. Philip Morris. Bates No. 2500048772/8781. http://legacy.library.ucsf.edu/tid/gag87e00.

57 Goddard CL. Q \& A. 17 Mar 1994. Philip Morris. Bates No. 2504061050/ 1052. http://legacy.library.ucsf.edu/tid//vw32e00.

58 Associated Press. The China News. Secondhand Smoke Causes Cancer, EPA Report Says. 7 Jan 1993. Philip Morris. Bates No. 2046323324. http:// legacy.library.ucsf.edu/tid/szb09e00.

59 Thomas H, Gagliardi J. Conspiracy: industry plants scientists to give friendly ETS Data. 1999. http://www.no-smoking.org/jan99/01-18-99-14.html [Accessed 12 Oct 2002]

60 Associated Press. The China Post. EPA Says Second-hand Smoke Causes Cancer. 7 Jan 1993. Philip Morris. Bates No. 2046323323. http:// legacy.library.ucsf.edu/tid/rzb09e00.

61 Ho A. The Freedoms that may go up in Smoke. 8 Jan 1993. Philip Morris. Bates No. 2046323306. http://legacy.library.ucsf.edu/tid/zzb09e00.

62 Chan F. South China Morning Post. Lobbyists Urge Widespread Smoking Ban in Wake of US Report. 8 Jan 1993. Philip Morris. Bates No. 2046323307. http://legacy.library.ucsf.edu/tid/aac09e00.

63 Malay Mail. Passive Smoking Causes Lung Cancer. Malay Mail. 8 Jan 1993. http://www.emedia.com.my/Services/database.html [Accessed 5 Feb 2003]. 
64 New Sunday Times. US Ties Second-hand Smoke to Cancer. New Sunday Times. 10 Jan 1993. http://www.emedia.com.my/Services/database.html [Accessed 5 Feb 2003].

65 Goddard CL. EPA Announcement. 13 Jan 1993. Philip Morris. Bates No. 2046323304. http://legacy.library.ucsf.edu/tid/dac09e00.

66 Anon. ETS Backgrounder: The Science on Environmental Tobacco Smoke (Consideration of a Western Issue from an Asian Perspective). 7 Jul 1996. Philip Morris. Bates No. 2065220688/0705. http://legacy.library.ucsf.edu/ $\mathrm{tid} / \mathrm{xnk83 \textrm {c } 0 0 .}$

67 Indoor Air International. International Conference: Indoor Air Quality in Asia. 18 Oct 1994. R.J. Reynolds. Bates No. 517605995/5996. http:// legacy.library.ucsf.edu/tid/knf30d00.

68 Walk RA. ETS Exposure Studies in Asia and Japan. 14 Aug 1995. Philip Morris. Bates No. 2063620104/0108. http://legacy.library.ucsf.edu/tid/ zdj67e00.

69 Lyons-Hart J. Suggestions for Future ETS Studies. 10 Feb 1988. Philip Morris. Bates No. 2023543421/3422. http://legacy.library.ucsf.edu/tid/ knn34e00.

70 Rupp JP. [Letter from John Rupp to Colleagues]. 28 Apr 1995. Philip Morris. Bates No. 2048770989/0990. http://legacy.library.ucsf.edu/tid/ xac55d00.

71 CIAR Presentation. Nov 1995. Philip Morris. Bates No. 2057790854/0866 http://legacy.library.ucsf.edu/tid/wim42d00.

72 National Association of Attorneys General. Master Settlement Agreement, http://www.naag.org/upload/1032468605_cigmsa.pdf [Accessed 11 Nov 2003].

73 Koo LC, Lee N. Do cooking fuels pose a risk for lung cancer? A case-contro study of women in Hong Kong. Ecol Dis 1983;2:255-65.

74 Koo LC. Dietary habits and lung cancer risk among Chinese females in Hong Kong who never smoked. Nutr Cancer 1988;11:155-72.
75 Tewes FJ, Koo LC, Meisgen TJ, et al. Lung cancer risk and mutagenicity of tea. Environ Res 1990;52:23-33.

76 Rylander R. PM on Discussions with Linda Koo, Hong Kong, November 5-6, 1992. Nov 1992. Philip Morris. Bates No. 2021527618/7620. http:// legacy.library.ucsf.edu/tid/ozz44e00.

77 Walk RA. Comments on Asian literature on ETS/Lung Cancer before 1992. 6 Jun 1994. Philip Morris. Bates No. 2045677096/7098. http:// legacy.library.ucsf.edu/tid/wir52e00.

78 RJRTI Public Relations. RJRTI News Report: Researchers in Hong Kong Say Diet, Not Smoke, Causes Lung Cancer Among Chinese. 28 Jun 1994. R.J. Reynolds. Bates No. 513204704/4704. http://legacy.library.ucsf.edu/tid/ qkh23d00.

79 Harris DS. Asia, ETS, Plans and Confusion. 11 Mar 1994. Philip Morris. Bates No. 2025495735A/5736. http://legacy.library.ucsf.edu/tid/ tdz88e00.

80 Walk RA. Plan for Asia 1996/1997. 29 Oct 1996. Philip Morris. Bates No. 2060565775/5807. http://legacy.library.ucsf.edu/tid/bzt18d00.

81 Walk RA 1 st Meeting of Asian Regional Tobacco Industry Scientists Team 'ARTIST' 24 May 1996. Philip Morris. Bates No. 2063834806/4808. http:// legacy.library.ucsf.edu/tid/duj32d00.

82 Murray W. Remarks by William Murray, Vice Chairman of the Board, Philip Morris Companies Inc. at the 1989 Philip Morris Legal Conference. 4 Apr 1989. Philip Morris. Bates No. 2023265282/5295. http:// legacy.library.ucsf.edu/tid/qpi46e00.

83 Philip Morris. Project Down Under Conference Notes. 24 Jun 1987. Philip Morris Bliley Collection. Bates No. 2021502102/2134. http:// tobaccodocuments.org/landman/23693.html [Accessed 11 Dec 2002].

84 Brady B. Unofficial Minutes of Asia Pacific Industry Affairs Meeting. 23 Aug 1994. British American Tobacco. Bates No. 502592934/2936. http:// tobacco.health.usyd.edu.au/tds/BAT502592934_2936 [Accessed 6 Feb 2003] 